\title{
THE EFFECT OF CLAYING UPON THE SETTLING OF THE SOIL SURFACE ON CULTIVATED SPHAGNUM BOGS
}

\author{
YRJÖ PESSI \\ Society of Peat Cultivation Experimental Station Leteensuo
}

Received Septemter 16, 1959

It is well known that the draining and cultivation of a bog produce a settling of the soil surface in the course of time. Numerous factors are responsible for this effect. When peat loses water, it tends to become compacted. Working machines, too, effect a compaction in peat. Cultivation of the surface layer of the bog, with fertilizing and soil improving agents, promotes microbial activity with a consequent increase in the rate of the decomposition processes of the peat substance. The changed conditions with respect to the air content also contribute to this effect. The resulting acceleration of humification is conducive to the establishment of a more compact peat structure. Furthermore, the settling of the soil surface is affected, e.g., by the wearing of the peat material in the tilled layer caused by the cultivation. It is thus obvious that there are numerous reasons for the settling of the soil surface produced by draining and cultivation. Methods have been developed which enable on to calculate in advance the extent of the settling of the bog surface $(1,2$, $4,5)$.

The present investigation covers a Sphagnum bog area that has been under cultivation for 35 years. We shall not study the absolute amount by which the surface of the bog has settled during this time, but rather the potential difference in this respect caused by claying and observable between the cayed and the unclayed bog areas.

\section{Test area}

This investigation was carried out in connection with a Sphagnum bog liming and claying test, the procedure and results of which have been described in detail in a previous publication (3). The location of the test members can be seen in detail from the map on p. 3 and a description of the test arrangements is found on p. 4 of the said publication. 
The peat layer on the test area has a thickness of about 3 meters. The peat is mainly composed of Sph. fuscum moss. In connection with the clearing for cultivation, the area was drained by open ditches dividing it into strips $20 \mathrm{~m}$ in withd. The clearing was done by hand hoeing in 1923. At this time one half of the strip $20 \mathrm{~m}$ in width between the ditches was clayed at $300 \mathrm{~m}^{3}$ clay per hectare. The test was combined with a liming test by applying varying lime quantities across both strips. The annual fertilization was equivalent to about $100-300 \mathrm{~kg}$ superphosphate, $200 \mathrm{~kg} 40 \%$ potassium salt and $100-300 \mathrm{~kg}$ calcium nitrate per hectare. Altogether 51 tons stable manure per hectare were given.

\section{Method of investigation and results}

The investigation was carried out in 1958, and as pointed out above, the object of the investigation was to determine the effect of the claying performed 35 years ago. The differences in elevation between the soil surfaces were studied by levelling in the following manner. The elevation of the soil surface was levelled at four points on each liming plot in the clayed as well as the unclayed strip. On each plot the points of measurement are on a straight line in the longitudinal direction of the strip and spaced at distances of 2 metres (the size of each plot was 5 by 10 metres; see 3 , map on p. 3). Thus altogether 100 points were levelled on the clayed as well as the unclayed strips. A board about $40 \mathrm{~cm}$ in length had been nailed to the lower end of the levelling staff to serve as a support in preventing the staff from entering the soft peat to a different depth in different instance and to eliminate the effect of minor irregularities in the soil surface.

According to a levelling survey carried out in 1949, the surface of the bog slopes at right angles to the clayed and unclayed strip at about $4 \mathrm{~cm}$ per 10 metres. The location of the test members with respect to the slope was such that the clayed strip had an inherently lower elevation than the unclayed strip. An appropriate correction was applied to the levelling results.

According to our results, the claying during the period of 35 years had made the surface of the soil settle on an average $12.5 \mathrm{~cm}$ more than was the case on unclayed bog. Statistical treatment by means of Student's $t$ test, taking the mean of four levellings to represent the soil surface elevation in each plot, yields a significance criterion of $\mathrm{P}$ less than 0.001 for the said $12.5 \mathrm{~cm}$ difference in elevation. The difference noted between the two strips is thus statistically highly significant.

This effect of the claying is due to various causes. Obviously we are concerned with differences both in regard to compaction of the peat and to its absorption. Being of considerably higher specific gravity than peat, clay directly effects a compaction of the latter. Moreover, among other things, clay increases the temperature of the cultivated layer during the growing season, with a consequent promoting effect upon microbial activities. This, in turn, produces more rapid humification with its attendant changes in physical characteristics. The differences in this respect are clearly evident in the test descriped above. It is probable that the increased microbial activity at the same time results in a more rapid wear of the peat substance. 
The present investigation concerns a Sphagnum bog area that has been under cultivation for 35 years. According to the results, the effect of the claying during this time has been the settling of the surface of the soil on an average $12.5 \mathrm{~cm}$ more than in unclayed bog.

REF E R E N C E S :

(1) Gerhardt, P. 1924. Landwirtschaftlicher Wasserbau. Ref. Segeberg 1952.

(2) Hallakorpi, I. A. 1932. Maatalouden vesirakennus, 360 pp. Porvoo.

(3) PEssi, Y. 1959. Kivennäismaan vaikutuksesta rahkasuon maanparannusaineena Leteensuon koeaseman pitkäaikaisten kenttäkokeiden perusteella. Summary: On the effect of mineral soil as a soil improving agent on Sphagnum bogs on the basis of prolonged field tests at Leteensuo experimental Station. Acta agr. fenn. 94. 14: 1-28.

(4) Segeberg, H. 1952. Untersuchungen über den strukturellen Aufbau von Mooren und zum Problem der Moorsackung. Wasser und Boden 6: 198.

(5) - - 1955. Untersuchungen über die Feststellung der Lage des Grenzhorizontes in Hochmoorprofilen sowie einige Bemerkungen über die Berechnung von Moorsackungen. Moor und Torf 7 .

S E L O T U S :

SAVEUKSEN VAIKUTUS MAAN PINNAN LASKEUTUMISEEN RAHKASUOVIL JELYKSELLÅ

YRJö PESSI

Suoviljelysyhdistys, Leteensuon koeasema

Esillä olevassa tutkimuksessa tarkastellaan, missä määrin maanparannus saveusta käyttäen on aiheuttanut eroavuutta rahkasuon pinnan laskeutumisessa saveamattomaan suohon verrattuna. Tutkimus on suoritettu v. 1958 rahkasuon kalkitus- ja saveuskokeesta, jota on yksityiskohtaisesti koetuloksineen selostettu aikaisemmin (3). Tutkimuskohteena oli tällöin siis 35 vuotta aikaisemmin suoritetun saveuksen vaikutus. Maan pinnan korkeuseroja tutkittiin vaakituksella. 35 vuoden aikana on savetun suon pinta laskeutunut keskimäărin $12.5 \mathrm{~cm}$ enemmän kuin saveamattoman suon pinta. Tarkasteltaessa tulosta t-testiä käyttäen saadaan savetun ja saveamattoman kaistaleen korkeuserolle P-arvo, joka on pienempi kuin 0.001.

Savetuksen vaikutus johtuu monista syistä. Ilmeisestikin on kysymyksessä saveuksen aiheuttamia eroavuuksia sekä turpeen tiivistymisessä että kulumisessa. Savi ominaispainoltaan huomattavasti suurempana kuin turve aiheuttaa suoranaisesti tiivistymistä siinä. Lisäksi savi kohottaa mm. muokkauskerroksen lämpötilaa kasvukauden aikana, mikä taas edistää mikrobitoimintaa. Tästä on seurauksena turpeen nopeampi maatuminen ja siten muutoksia sen fysikaalisissa ominaisuuksissa. Selostetussa kokeessa eroavuudet ovat silmin havaittavia. Tehostunut mikrobitoiminta johtanee samalla turveaineen nopeampaan kulumiseen. 